\title{
Composition of the word family with the root * svęt- in historical dictionaries of the Russian language
}

\author{
Iuliia Koreneva ${ }^{1, *}$ \\ ${ }^{1}$ Moscow Region State University, 10A, Radio str., Moscow, 105005, Russia
}

\begin{abstract}
The article is devoted to the comparative analysis of the word family with the root -свят/свящ- based on historical dictionaries of the Russian language, the purpose of the study is to conduct a preliminary analysis of the presentation of the words of this family in different dictionaries of the Russian language, namely, historical and modern. The statistical approach to lexical data demonstrates that the data obtained from five historical dictionaries contain a large number of words that no longer function in the modern Russian language, compared to certain dictionaries of modern Russian. I.I. Sreznevsky's Dictionary includes 105 words; Dictionary of Old Russian Language (11th-14th centuries) has 73 words; Russian Dictionary XI-XVII Centuries involves 210 words; Dictionary of the Russian Academy includes 61 words; Dictionary of the Church Slavonic language of 1847 has 150 words; Explanatory Dictionary of the Russian Language by Vladimir Dahl involves 124 words. When comparing quantitative data in all the historical dictionaries, the largest group comprises lexemes with the secondary root -свящ-. Moreover, all the words of this word family are not only etymologically related, but have the same root, since they maintain unity in their seme content that allows to analyze the semantic density of the root. In addition, a homogeneous stylistic marking of words of the word family also confirms their affinity, as all the words of this word family are genetically related to Church Slavonic and belong to the religious sphere. Graphs of the use of the words святой, святость (saint, sanctity) and священный (holy) based on the Russian National Corpus demonstrate a decrease in the frequency of these words since the middle of the 19th century, and a comparison of the list of words of this word family from each historical dictionary with the modern linguistic consciousness directly indicates a drastic reduction in quantitative content of this word family, that occurred due to extralinguistic (historical and ideological) reasons.
\end{abstract}

\section{Introduction}

The study of words of one etymological family of words in the Russian language is associated with scientific problems of semantic transformation of each word, changes in derivational relations between units of a word family in the course of time, as well as the

\footnotetext{
*Corresponding author: uv.koreneva@mgou.ru
} 
influence of extralinguistic factors and other reasons, a detailed analysis of which is possible when referring to particular groups of words. The research at hand is devoted to the problems of historical lexicology of the Russian language and concerns the issue of lexicographic presentation of words with the Slavonic root *svęt-, which is implemented in Russian in two forms: -свят- and -свящ-. The second root contains the South Slavic reflex of changing the dental $-m$ - (-t-) under the influence of the phoneme $<j>$. Etymologically, the root traces its origin to the sound complex with the basic meaning of growth, extension, expansion (more information on the etymology of this root: [1]). In modern Russian, this family of words with the same root includes units of different parts of speech, the root of which has one of two realizations: святой (saint), священный (holy), посвятить (to ordain), освящать (to consecrate), etc. It should be noted that the words of this family in modern Russian have the same origin, as well as the same root with different types of derivational relations between them. This aspect is significant, since, in the course of time, many words that originate from the same ancient root, lose their formal-semantic relations and cease to be perceived as words with the same root, while being etymologically related

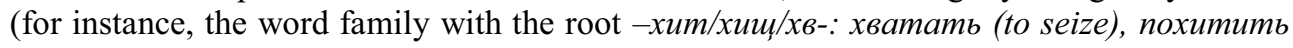
(to abduct), восхищение (admiration) or the root -pyd/pыж)/рд-: руда (ore), рыжеть (to turn reddish), рысь (lynx), рдяный (scarlet), etc.). The reasons for non-discrepancy in the formal-semantic relations of words containing this root may lie in the discursive establishment of their semantics and usage, such word family is semantically dense and stylistically homogeneous.

The history of the words of the word family as a whole has not yet been an independent object of a separate linguistic study, the discussion on this topic is regarded as the initial stage in the study of the word family from the perspective of Russian historical lexicology. The purpose of the study is to conduct a preliminary analysis of the presentation of the words of this family in different dictionaries of the Russian language, namely, historical and modern. The presence of a word in lexicographic record allows to study the development of vocabulary of a language. In relation to the words containing the root under discussion, such development is of great interest, since the whole word family is semantically and historically included, firstly, in the religious semantic field of the language, and secondly, in the stylistically marked group of linguistic units.

\section{Materials and methods}

The reference to dictionary data is explained by the fact that it is associated with the methodology of historical lexicology and historical semantics of the Russian language [2]. Although lexicographic data, as is known, cannot reflect the full semantic volume of a word (more information on the specifics of lexicographic value: [3]), the dictionary records linguistic units in isolation.

Historical dictionaries based on ancient manuscripts are of crucial value for the solution of the problems of Russian historical lexicology: [4]. New objectives of modern Russian lexicography have led to the appearance of a new type of dictionary: [5]. Furthermore, as a source of information about the specifics of the development of words in the words family under consideration, the sources of the Russian National Corpus have been applied [6].

The objective of the study is to identify words with the root under discussion in particular dictionaries and to conduct a statistical comparison of the presence of words in different dictionaries to establish the corpus of units that are included in the active vocabulary of the modern Russian language. In the future, the study of changes in the semantics of each of such words would allow to create a fairly complete picture of the semantic transformation and changes in derivational relations of words of a common word family. The major research method is the method of comparing vocabulary data with the 
application of a synchronic-diachronic approach and the statistical method based on a quantitative analysis of the presentation of words of the particular word family in a certain dictionary.

\section{Results and discussion}

As stated above, the specific researches on the words of this word family as a whole have not been found, therefore the material provided in the article is included in the current paradigm of a scientific study of Russian historical lexicology and is considered to be the first experience - in connection to the words of the word family - of comparing dictionary units in a synchronic-diachronic perspective.

The words of the word family under consideration have partially been studied basing on the I.I. Sreznevsky's Dictionary and the results are presented in: [7]. The general questions of historical lexicology of the Russian language could be found either in single studies or in various collections of scientific papers. Unfortunately, it should be noted that in the historical Russian philology, despite a sufficient number of single studies and authoritative monographs, there is no complete description of the development of the Russian vocabulary, which is explained, according to the author, not by the absence of research intent, but by the specifics of the lexical-semantic level of the language, which is impossible to describe retrospectively, covering all lexical layers. Taking into account the incompleteness of the approach to the problems of Russian historical lexicology, it is noted that the need for such a study is extremely significant.

The semantic-stylistic specificity of the words of the considered word family involves their religious genesis, which affects their semantic development and the possibility of actualization in the modern usage. The research interest in the language of religion, the religious vocabulary of the Russian language, as well as linguistic markers of various religious concepts, especially in the context of studying the Church Slavonic language, has been considerable in the last two decades: [8], including the framework of lexicographic publications: [9]. As could be seen from the list of the research literature, the interest in the topic under discussion has a high scientific status and serious scientific reflection.

In the recent work of the author, in the process of analysis of the composition of the word family in the I.I. Sreznevsky's Dictionary, 105 words of this word family have been identified, 14 of which, after examining the Russian National Corpus, have been singled out as an independent group of units that have been preserved at the present stage: святой (saint), священник (a priest), священный (holy), святитель (a saint bishop), святыня (a relic), святость (holiness), священнослужитель (an ecclesiastic), священство (priesthood), святилище (a shrine), священнический (priestly), освятить (to consecrate), священнодействовать (to perform a religious rite), святотатеи (a sacrileger), святить (to consecrate) [10]. The presentation in the Corpus is indicative since it can be used to trace the dynamics of obsolescence and, on the contrary, the modern actualization of the use of a certain word. Certainly, the 14 words selected as a result of the analysis of the I.I. Sreznevsky's Dictionary do not represent the full set of words of this root in the modern Russian language. There are no units of the word family of the modern verb святить (to consecrate) in this list: святить: посвятить (to consecrate), посвящение (ordaining), посвященный (ordained), etc. This observation has been made since the I.I. Sreznevsky's Dictionary is the first and unique dictionary that have records about the Old Russian lexicon based on ancient manuscripts, and it would be interesting to learn which words remained and which ones disappeared. Undoubtedly, this view does not involve the material of the entire remaining period of the language development, therefore, there is a need to research the data presented in other historical dictionaries. Dictionary of the Old Russian language of the XI-XIV centuries and The Russian Dictionary of the XI-XVII 
centuries are the ongoing lexicographic publications, which, as well as the I.I. Sreznevsky's Dictionary, are based on ancient manuscripts. However, it is still impossible to obtain final statistics from these dictionaries due to the lack of a complete set of volumes. Thus, for instance, there is still no corresponding volume of the Dictionary of the Old Russian language on the letter $\mathrm{T}$, therefore it is impossible to analyze the lexeme Трисвятый (Trisagion). Consequently, the material obtained from this dictionary only include prefixless words with the root under discussion). In the Dictionary of the XI-XIV centuries, there are 73 lexemes (without semantic and graphical duplication of words, for example, свящеНический and свящеННический (priestly) are regarded as one lexeme, although the dictionary provides the article for each word), in the Dictionary of the XI-XVII centuries, there are approximately 210 words with this root. Dictionary of the Russian Academy, which records the Russian language of the XVIII century, contains 61 words, and Dictionary of the Church Slavonic and Russian language, compiled by the Second Department of the Imperial Academy of Sciences, contains 150 words. The arrangement of the dictionary material according to the word families is peculiar only to Dictionary of the Russian Academy and Dahl's Explanatory Dictionary, in which 124 units are recorded in the article of the word святой (saint) (Dahl's Explanatory Dictionary is included in the list of historical dictionaries of the Russian language [11]). The other dictionaries are organized according to the standard alphabetical order, which, on the one hand, is convenient and corresponds to the generally accepted rules, but is problematic in the process of analysis of the dictionary material, on the other hand. In addition, the time of publication of a dictionary does not have a strict correlation with a decrease or increase in the number of words in the family:

Table 1. Number of units of the word family in historical dictionaries.

\begin{tabular}{|l|l|l|}
\hline \multicolumn{1}{|c|}{ Dictionary } & \multicolumn{1}{|c|}{$\begin{array}{c}\text { Year of } \\
\text { publication }\end{array}$} & $\begin{array}{l}\text { Number of words } \\
\text { of the word } \\
\text { family }\end{array}$ \\
\hline I.I. Sreznevsky's Dictionary & 1893 & 105 \\
\hline $\begin{array}{l}\text { Dictionary of the Russian language in the XI-XVII centuries, } \\
\text { vol. 3, }\end{array}$ & $\begin{array}{l}1976, \\
\text { vol. 17, } \\
\begin{array}{l}\text { vol. 19, } \\
\text { vol. 23 }\end{array}\end{array}$ & $\begin{array}{l}1991, \\
1994, \\
1996\end{array}$ \\
\hline $\begin{array}{l}\text { Dictionary of the Old Russian language of the XI- } \\
\text { XIV centuries (vol. 11) }\end{array}$ & 2016 & 73 \\
\hline Dictionary of the Russian Academy & $1789-1794$ & 61 \\
\hline Dahl's Explanatory Dictionary & $1863-1866$ & 124 \\
\hline $\begin{array}{l}\text { Dictionary of the Church Slavonic and Russian language, } \\
\text { compiled by the Second Department of the Imperial } \\
\text { Academy of Sciences, 1847 }\end{array}$ & 1847 & 149 \\
\hline
\end{tabular}

As demonstrated above, the largest composition of the word family is recorded in the Dictionary of the Russian language in the XI-XVII centuries.

Both roots are presented unevenly, in the lists of different dictionaries. Data on forms of the root *svęt- are presented in Table 2 .

Table 2. Statistics on forms of the root in dictionaries.

\begin{tabular}{|l|c|c|}
\hline \multicolumn{1}{|c|}{ Dictionary } & $\begin{array}{c}\text { The root } \\
\text {-свяm- }\end{array}$ & $\begin{array}{c}\text { The root } \\
\text {-свящ- }\end{array}$ \\
\hline I.I. Sreznevsky's Dictionary & 46 & 58 \\
\hline Dictionary of the XI-XIV centuries & 32 & 41 \\
\hline Dictionary of the XI-XVII & 92 & 118 \\
\hline
\end{tabular}




\begin{tabular}{|l|l|l|}
\hline centuries & & \\
\hline $\begin{array}{l}\text { Dictionary of the Russian } \\
\text { Academy }\end{array}$ & 25 & 36 \\
\hline Dahl's Explanatory Dictionary & 70 & 54 \\
\hline $\begin{array}{l}\text { Dictionary of the Church Slavonic } \\
\text { and Russian language }\end{array}$ & 62 & 88 \\
\hline
\end{tabular}

It should be noted that in all historical dictionaries, a considerable part of words of the word family are compound words. In the Russian language compounds have the peculiar history of study. However, in the context of Church Slavonic-Greek and then Church SlavonicRussian relations, especially in the field of religious-related words, compounding is considered to be a method of borrowing that has assimilated on the East Slavic land.

Table 3. Number of compound words in dictionaries.

\begin{tabular}{|l|c|c|}
\hline \multicolumn{1}{|c|}{ Dictionary } & $\begin{array}{c}\text { Compound words with } \\
\text { the root -свяm- }\end{array}$ & $\begin{array}{c}\text { Compound words with } \\
\text { the root -свящ- }\end{array}$ \\
\hline I.I. Sreznevsky's Dictionary & 15 & 31 \\
\hline Dictionary of the XI-XIV centuries & 12 & 25 \\
\hline Dictionary of the XI-XVII centuries & 44 & 77 \\
\hline Dictionary of the Russian Academy & 7 & 19 \\
\hline Dahl's Explanatory Dictionary & 32 & 36 \\
\hline $\begin{array}{l}\text { Dictionary of the Church Slavonic and } \\
\text { Russian language }\end{array}$ & 25 & 58 \\
\hline
\end{tabular}

The comparison of the data in tables (2) and (3) displays that, in almost every case, composites comprise at least $50 \%$ of the total number of words with both roots. This observation could form the basis for a separate scientific study, which would also reveal the time of the appearance of such compound words in the Russian language and the reasons for it, as well as their functioning in texts, and the time and reasons for the disappearance from the Russian lexicon.

Moreover, it should be noted that words with the root -свям- are derivationally secondary, since the original form of the root contains the plosive $-m-$, which has been changed into $-m$ - under the terms of the yod-coalescence. The East Slavic result of changes in the final consonant of this root has not been entrenched in the Russian language (words with the root -свяч- have not been found in the analyzed dictionaries, except for the lexeme свяченые (saint) appearing in [12]). Therefore, the prevalence of units with the root variant -свяи- in most historical dictionaries is remarkable, which once again highlights the Church Slavonic genesis.

In the process of comparison of the lexicographic data, the following provisions are selected as the starting point of the analysis: 1) the reflexive form of a base verb is not considered to be an independent unit in when the suffix - $c я$ performs the inflectional function (посвящаю - посвящаюсь (to ordain));

2) the use of the same word as part of set structures is not regarded as a separate lexeme (освящение (consecration)- Освящение Храма (the consecration of a church); священный (holy) - Священное Писание (Holy Scripture));

3) morpheme-derivational versions of words with the identical definition are recognized as one lexical unit (священнодейство - священнодействие (sacrament));

4) the feminine unit that is correlative to the masculine lexeme, is considered to be a separate word (святотатеи - святотатица (a sacrileger, masculine and feminine)).

Thus, taking into account the indicated conditions, the following units with the corresponding roots are presented in the dictionaries:

Table 4. A summary list of words with both roots. 


\begin{tabular}{|c|c|c|}
\hline Dictionary & Words with the root - свяm- & Words with the root -свящ- \\
\hline $\begin{array}{l}\text { Dictionary } \\
\text { of the } \\
\text { Russian } \\
\text { Academy } \\
{[13]}\end{array}$ & $\begin{array}{l}\text { святыій, святеи, Трисвятый, } \\
\text { святейший, } \\
\text { святейшество, свято, } \\
\text { святость, } \\
\text { святолепный, святотатеи, } \\
\text { святотатство, } \\
\text { святотатствую, } \\
\text { святилище, святки, } \\
\text { святошный, } \\
\text { святьия, пустосвят, } \\
\text { пустосвятство, } \\
\text { святиьь }\end{array}$ & 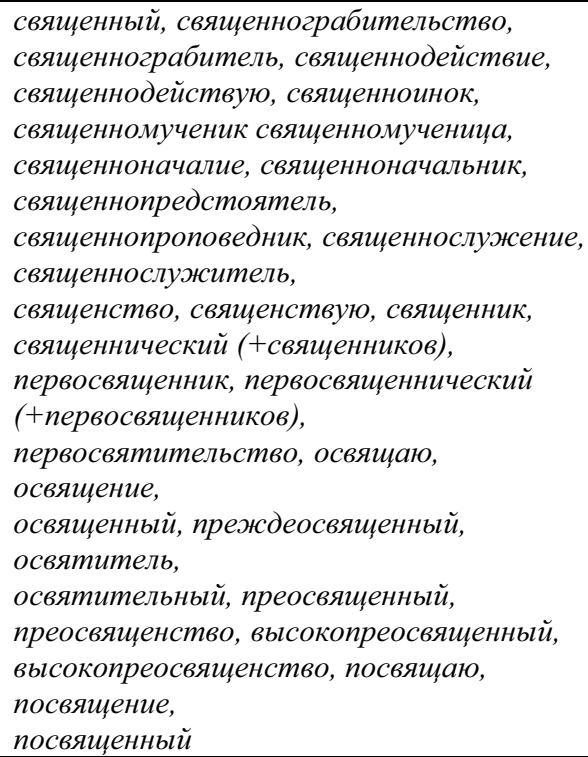 \\
\hline $\begin{array}{l}\text { I.I. } \\
\text { Sreznevsky's } \\
\text { dictionary } \\
\text { [14] (the } \\
\text { lexemes are } \\
\text { given in } \\
\text { modern } \\
\text { writing) }\end{array}$ & $\begin{array}{l}\text { Всесвятый, освятити, } \\
\text { освятитися, освятение, } \\
\text { пресвятый, святилише, } \\
\text { святие, святильник, } \\
\text { святителевати, святителев, } \\
\text { святитель, святительный + } \\
\text { святительский, святительски, } \\
\text { святительство, } \\
\text { святительствовати, святити, } \\
\text { святолепьй + святолепный, } \\
\text { святолепне, святописание, } \\
\text { святопобедник, святопевеи, } \\
\text { святость, святословный, } \\
\text { святостный, святосделавати, } \\
\text { святостяжати, } \\
\text { святотатица, святотатеи, } \\
\text { святоунырение, святок, } \\
\text { святый, святыня, святьба, } \\
\text { святец, Трисвятый, } \\
\text { лжесвятитель, святило, } \\
\text { святованый }\end{array}$ & 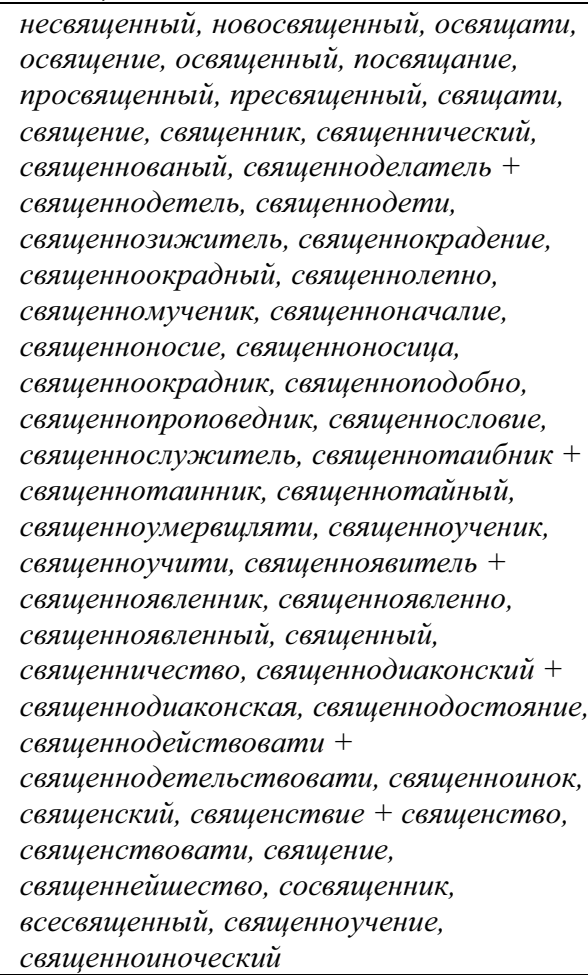 \\
\hline $\begin{array}{l}\text { Dictionary } \\
\text { of the XI- } \\
\text { XIV } \\
\text { centuries } \\
{[15]} \\
\text { (the lexemes } \\
\text { are given in } \\
\text { modern }\end{array}$ & $\begin{array}{l}\text { святилище, святителев, } \\
\text { святитель, святительный, } \\
\text { святительски, святительский, } \\
\text { святительствие, } \\
\text { святительство, } \\
\text { святительствовати, святити, } \\
\text { свято, святованный, } \\
\text { святовидец, святовещаный, }\end{array}$ & 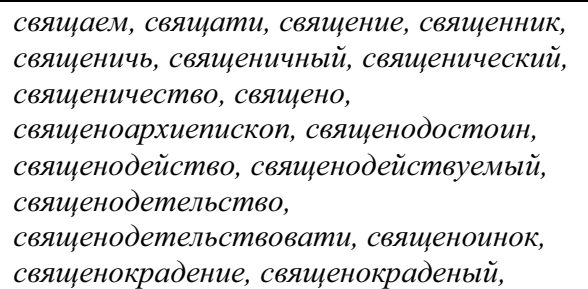 \\
\hline
\end{tabular}




\begin{tabular}{|c|c|c|}
\hline writing) & $\begin{array}{l}\text { святокрадец, святолепый } \\
\text { (+святолепен), святомученик, } \\
\text { святопомазаный, } \\
\text { святопочивиий, } \\
\text { святопсалтырник, святопевеи, } \\
\text { святоразумный, святость, } \\
\text { святотатство, святотатеи, } \\
\text { святок, святый, святыня, } \\
\text { святьба, святство, святеи, } \\
\text { святеи }\end{array}$ & 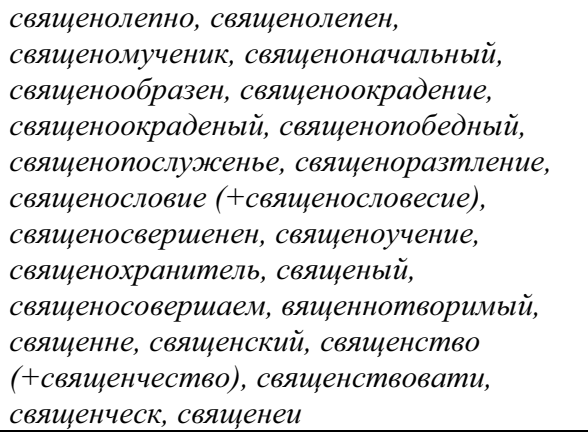 \\
\hline $\begin{array}{l}\text { Dictionary } \\
\text { of the XI- } \\
\text { XVII } \\
\text { centuries. } \\
{[16]} \\
\text { (the lexemes } \\
\text { are given in } \\
\text { modern } \\
\text { writing) }\end{array}$ & 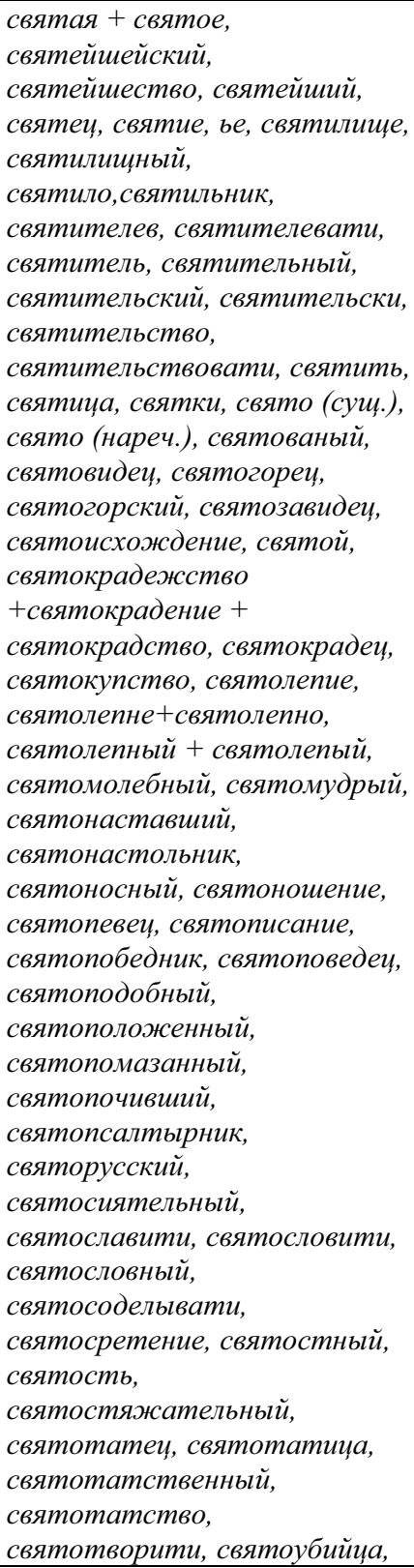 & 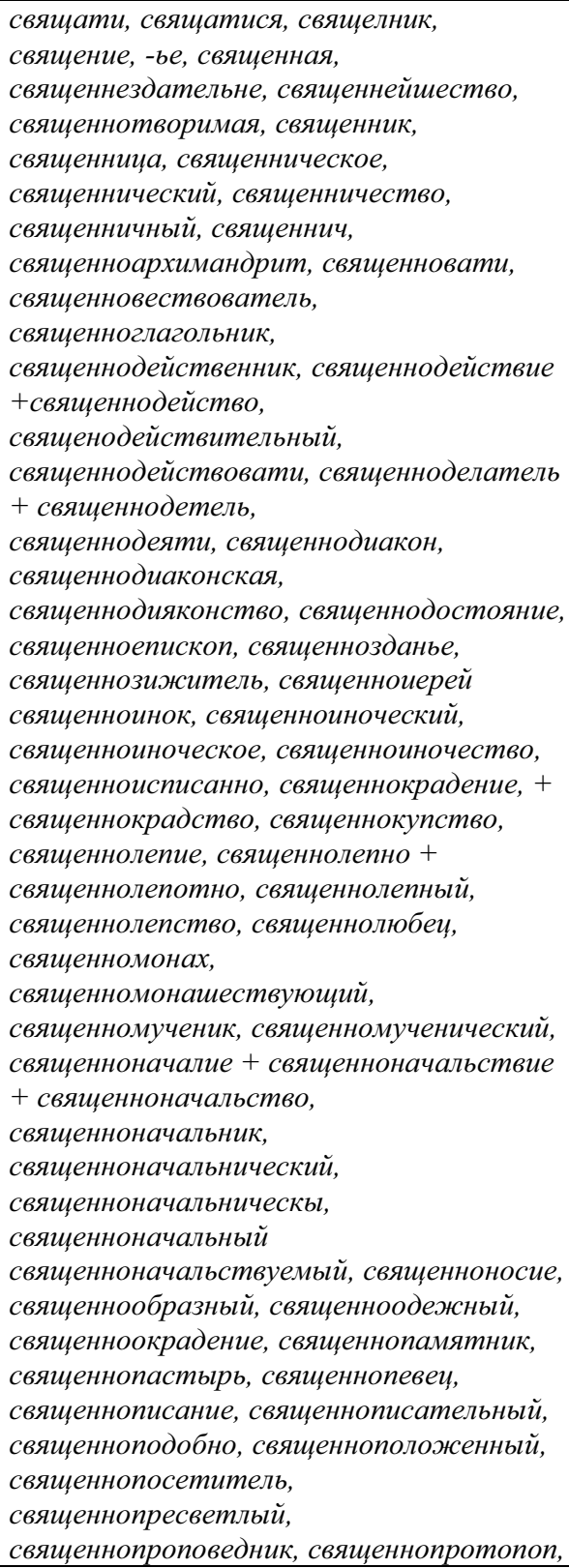 \\
\hline
\end{tabular}




\begin{tabular}{|c|c|c|}
\hline & 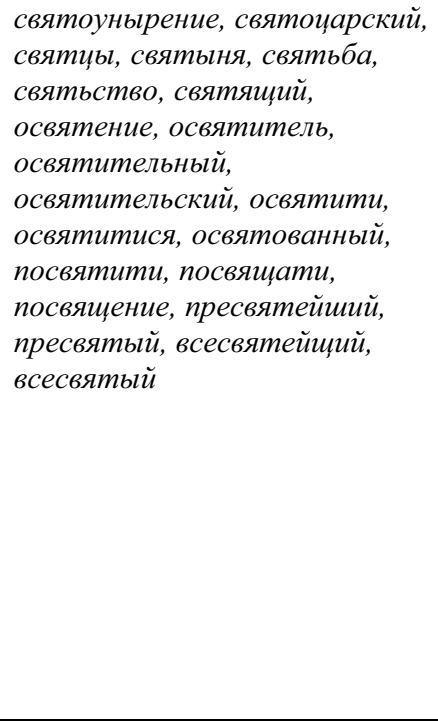 & 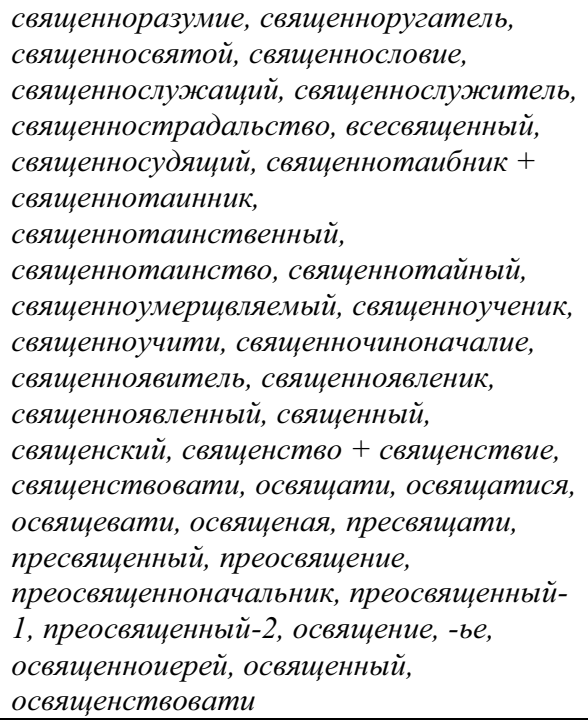 \\
\hline $\begin{array}{l}\text { Dictionary } \\
\text { of the } \\
\text { Church } \\
\text { Slavonic } \\
\text { and Russian } \\
\text { language } \\
\text { [17] } \\
\text { (the lexemes } \\
\text { are given in } \\
\text { modern } \\
\text { writing) }\end{array}$ & 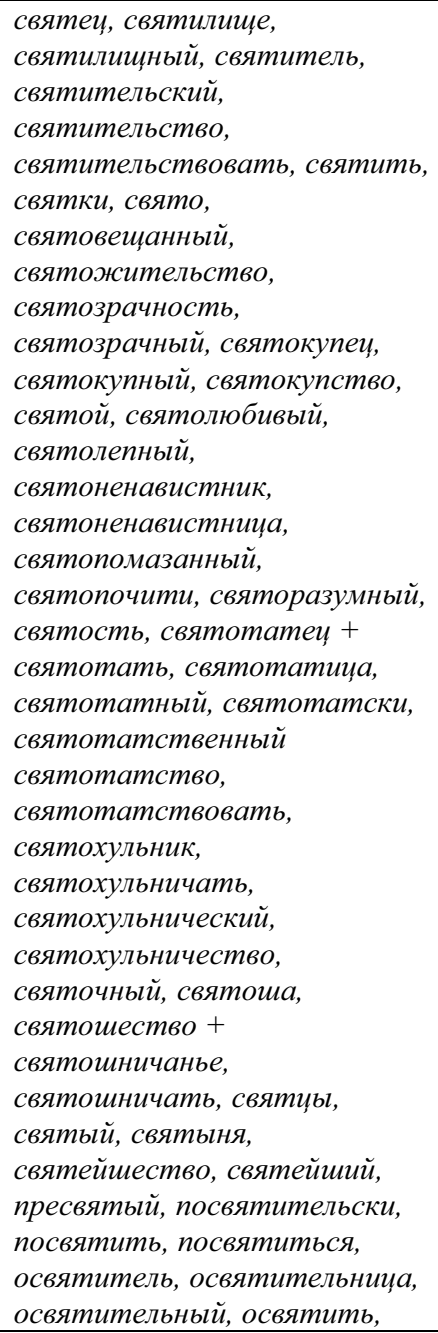 & 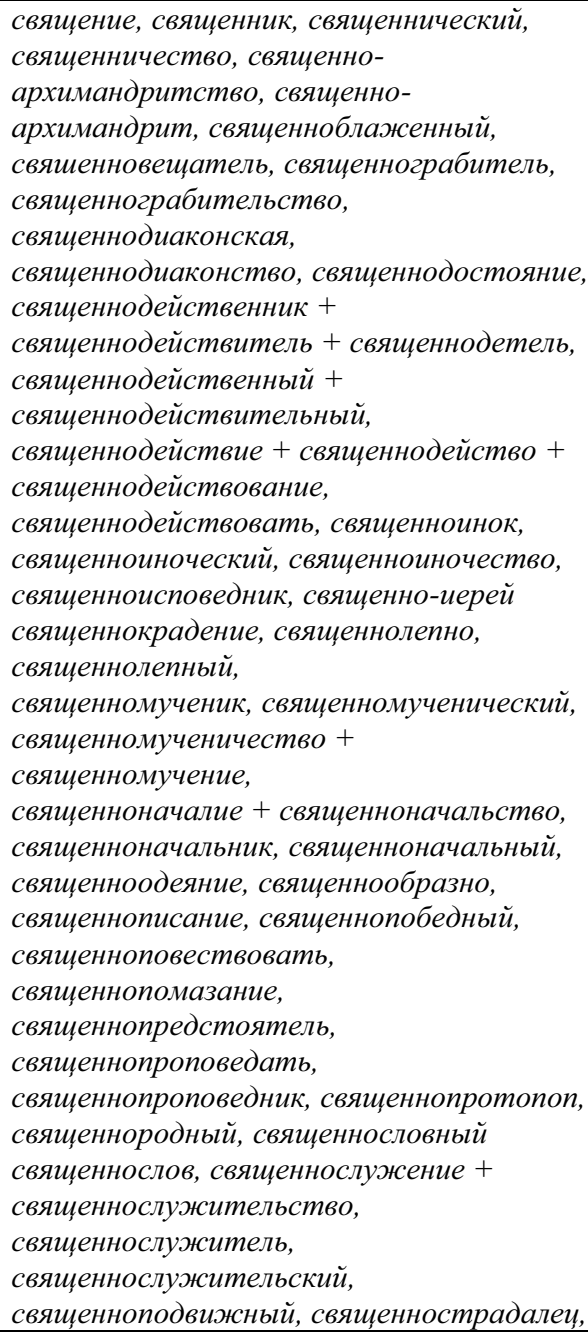 \\
\hline
\end{tabular}




\begin{tabular}{|c|c|c|}
\hline & освятиться & 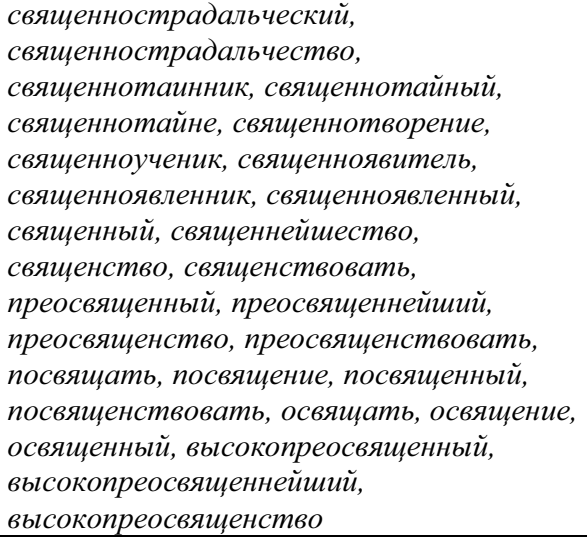 \\
\hline $\begin{array}{l}\text { Dahl's } \\
\text { Explanatory } \\
\text { Dictionary } \\
{[18]}\end{array}$ & 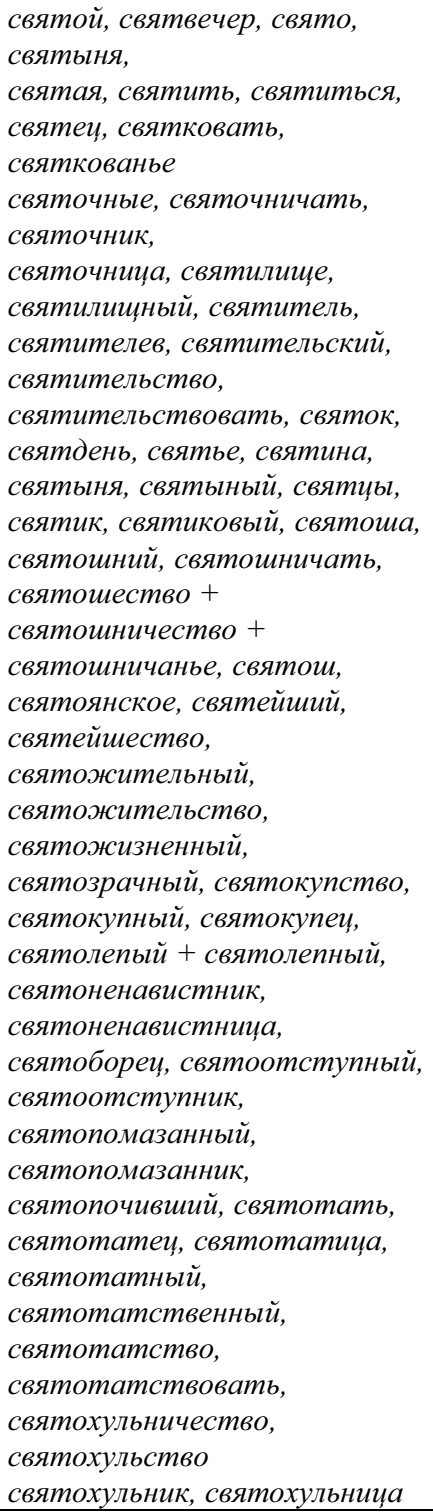 & 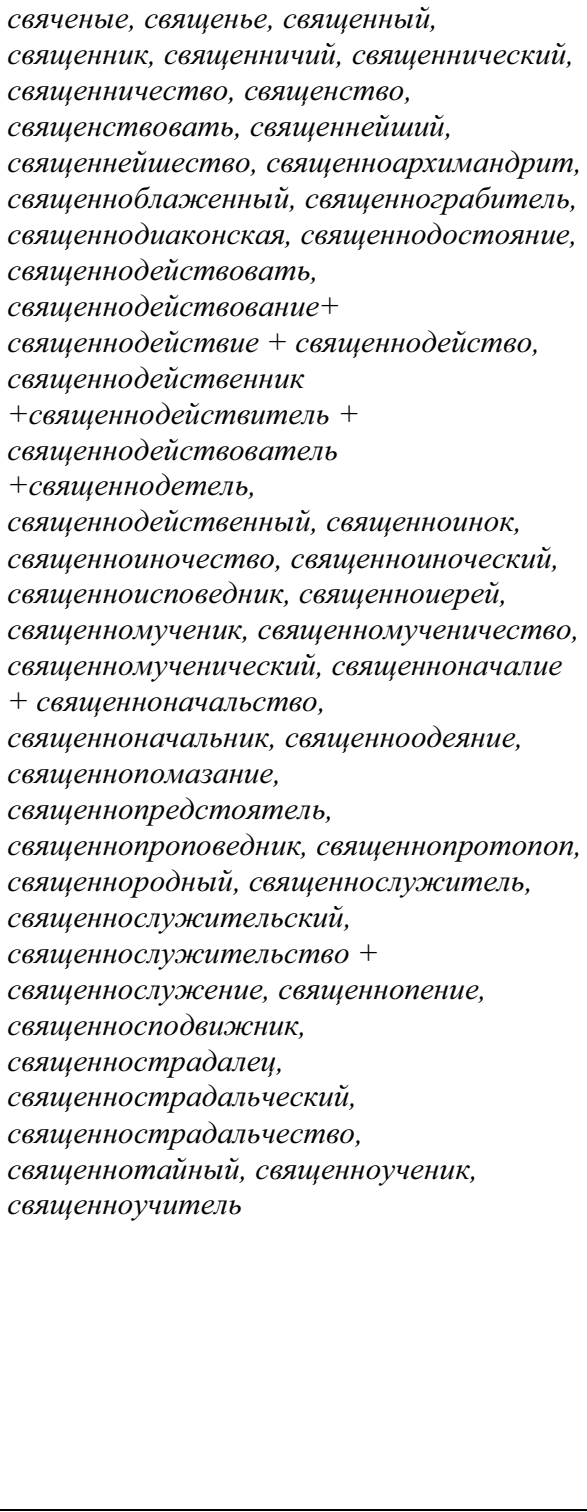 \\
\hline
\end{tabular}


The research of the word list in the dictionaries and the "application" of this list to modern linguistic consciousness indicates that most of the words are not actively used in the modern Russian standard language. Special attention should be paid to this observation. Firstly, since the active vocabulary is a rather subjective matter and depends on a particular native speaker, there is a risk that the issue of the inclusion of words in a certain sphere of vocabulary would be resolved too generally. Secondly, the family of words with the root under consideration is part of the Russian religious discourse and the conceptual framework, and it is necessary to analyze the correlations between the Russian and Church Slavonic languages, in which there are words and notions that are not included in the active Russian word usage. This leads to the problem of the Church Slavonic terminology: a person who is familiar and who has a high level of the modern Russian standard language, including Church Slavonic borrowings and obsolete words, would understand many words correctly, unlike a native speaker who is not familiar with the Church Slavonic language. This thesis is fairly accurately verified with a social survey through social networks (however, a number of social factors restricting the audience interfere), which is not included in the objectives of this discussion, but may become one of the aspects of the study of this issue in the future.

The active word usage can be traced with the data obtained from the dictionaries that record the Russian language of the 20th century. When analyzing three dictionaries, namely, Ushakov's Dictionary [19], Small Academic Dictionary [20] and Dictionary of the Russian Language by Ozhegov S.I. and Shvedova N.Yu.) [21], the absence of most of the words of the considered word family, recorded by the historical dictionaries, is indicative: 80 words out of 105, basing on I.I. Sreznevsky's Dictionary, are not found in all three of these dictionaries, among which there are such lexemes as: Всесвятый, несвященный, новосвященный, святильник, святительный, святительство, святительствовать, святолепный, святописание, святопобедник, святопевеи, святословный, святосделавати, святостяжати, святотатииа, святеи, священнокрадение, священномученик, священноумервщляти, etc. Many of these words are obsolete at the present stage of the development of the Russian language (священноносие, священнотаибник, святосретение, святохульничество, etc). It is peculiar that in Dictionary of the Russian Language by Ozhegov S.I. and Shvedova N.Yu. there is no such word as святость. Russian National Corpus, as stated above, makes it possible to trace the dynamics of actualization of a word in the course of time. Certainly, Russian National Corpus cannot be considered to be the primary source of the language material, and not all Russian texts are presented in the Corpus (this is an almost impossible task), however, the results of the Corpus are relevant.

The dynamics of the frequency of the word usage is the following (for the demonstration of the results, the units святой (saint), святость (holiness) and священный (holy), presented in the Corpus, have been selected: the search has been carried out in the old version of the website of Russian National Corpus, since, in the new version, the statistics graphs were not available at the time of the study): святой (saint) - 48622; святость (holiness) - 2745; священный (holy) - 14156 mentions. The graphs of the Corpus provide a sample of frequency for the period from 1800 till 2014.

1) For the lexeme святой (saint), the peak of usage is in the chronological range from approximately 1820 till 1860 . (above 300 uses, with an abrupt decline in the 50s of the 19th century and a subsequent secondary rise in the 60s). Starting in the 80s of the 19th century, until approximately 1980, the graph is in the "flat" zone of usage. In the 90s of the 20th century, there is another rise and a gradual smooth decline with reaching a plateau in the 2000s. [22]; 
2) For the lexeme святость, the graph's peak values reflect the chronological segments of around 1820 and 1920. In addition, the use of the lexeme in texts of the 19th century during this time period is twice as frequent in the texts of the 20th century, the period of time from the 40 s of the 19 th century till the early 20th century and from the 20 s of the 20th century till its end display relatively smooth dynamics with a certain decrease in frequency in the 2000s [23];

3) for the lexeme священный (holy), the graph provides information on its extremely high frequency of usage in the period of the 20-30s of the 19th century with an abrupt decline in use in the 40 s of the same century and approximately the same frequency from that time until 2014 [24].

In addition, the use of these words is represented with texts of various genres, in which, regardless of the time of creation and the subject, the religious component of semantics is preserved. According to all the three graphs, it is evident that, in the 20th century, the use of these units was decreased, which began approximately in the middle of the 19th century. This is explained by the extralinguistic factors: in the 20th century, there is a change of ideology in the country, resulting not only in a reduction in the use of words of this word family and the obsolescence of some units and their disappearance from the standard language, but also in emergence of new meanings, mechanisms of semantic transformation of which were started in the middle of the 19th century, for instance, the word святой (saint) obtains the sememes such as "благородный, освященный высокой иелью (nоble, honoured with a high purpose)"; "такой, который должен быть выполнен в силу своего высокого значения; обязательный, непреложный (the one that should be accomplished due to its high value; mandatory, inviolable)"; "незыблемый, нерушимый (sacrosanct, unbreakable)"; "безусловный, полный (unconditional, complete)" [25]. These changes are associated both with the constitutive features of the lexical system as a whole and with the general trend of the Russian lexicon in the period of formation and establishment of the modern norms of the Russian standard language, the result of which is the development of new meanings.

\section{Conclusion}

The consideration of this word family and the analysis of its changes in dictionaries is determined by the approach that could be called mental-linguocultural in modern Russian linguistics. "In respect of the Russian linguistic consciousness, the Russian mentality is associated with morality, humanity, the spirituality of the people, as well as soulfulness which is an extremely important quality of the Russian mentality, the love for the motherland and holiness" [26]. Moreover, the research in this field from the formalsemantic perspective concern the semantics in its synchronic-diachronic presentation, which is partially demonstrated in the material at hand, as well as the etymologicalderivational relations that restore the original directions of word correlations (the pattern of such correlations can be found on the website [27], which is a unique educational online resource that answers the questions on etymological-derivational connections of Russian words).

There are a lot of issues beyond the scope of this material, which can and should constitute the prospects for the research. They are: the chronological framework of the emergence and disappearance of words of the considered word family in the Russian language with the study of the reasons for the obsolescence of a particular unit; derivational development of words of the word family and restructuring of derivational relations between words of the word family in diachronic terms; changes of the semantics of words of this word family that remain in the modern Russian language in diachronic terms; specificity of appearance and semantization of the composite words of this word family; 
identification of the causes of semantic density of the word family and verification of this density with ancient manuscripts; functioning of words of the word family in the Russian and Church Slavonic texts of different time periods and the comparative analysis of established semantics in the Church Slavonic and Russian languages, in this perspective; and functionality of certain units of the word family in the Eastern Orthodox conceptual framework and religious texts of various genres.

It seems that a similar plan of analysis can be applied to other etymological families of Russian words.

\section{References}

1. V.N. Toporov, Sviatost' i sviatye v russkoi dukhovnoi kul'ture. Tom 1. Pervyi vek khristianstva na Rusi (M., «Gnozis» - Shkola «Iazyki russkoi kul'tury», 1995)

2. L.Iu. Astakhina, Vestnik PSTGU. III: Filologiia 1(11), 7 (2008)

3. V.V. Vinogradov, Izbrannye trudy. Leksikologiia i leksikografiia (M., 1977)

4. E.V. Generalova, Dinamika iazykovykh i kul'turnykh protsessov v sovremennoi Rossii 5, 1437 (2016)

5. N.V. Piataeva, Istoricheskaia leksikologiia russkogo iazyka: dinamicheskoe opisanie etimologicheskikh gnezd: ucheb.posobie (M., 2018)

6. Russkaia istoricheskaia leksikologiia. Sb. statei (M., 1968)

7. I.S. Ulukhanov, Istoricheskoe slovoobrazovanie. Istoricheskaia leksikologiia (M., 2012)

8. F.P. Filin, Istoricheskaia leksikologiia russkogo iazyka. Prospekt (M., 1984)

9. P.Ia. Chernykh, Ocherk istoricheskoi leksikologii. Drevnerusskii period (M., 2010)

10. Z.D. Popova, I.A. Sternin, Leksicheskaia sistema iazyka: Vnutrenniaia organizatsiia, kategorial'nyi apparat i priemy opisaniia. Uchebnoe posobie (M., 2010)

11. Materials for the dictionary of the Old Russian language. The works of Sreznevsky I.I., http://etymolog.ruslang.ru

12. Dictionary of the Russian Academy. St. Petersburg, 1794; Dictionary of the Russian language in the XI-XVII centuries (M., 1975)

13. Dictionary of the Church Slavonic and Russian language, compiled by the Second Department of the Imperial Academy of Sciences (Saint Petersburg, 2001)

14. V.V. Kolesov, D.V. Kolesova, A.A. Kharitonov, Dictionary of Russian Mentality (Publ. Saint Petersburg, 2014)

15. Russian Semantic Dictionary. The explanatory dictionary organized by classes of words and meanings (M., 1998)

16. Sistema leksicheskikh minimumov sovremennogo russkogo iazyka: 10 leksich. spiskov: ot 500 do 5000 samykh vazhnykh slov (M., 2003)

17. Russian National Corpus, http://ruscorpora.ru/old/

18. Iu.V. Koreneva, Fortunatovskie chteniia v Karelii. Sbornik dokladov mezhdunarodnoi nauchnoi konferentsii (Petrozavodsk, 2018)

19. K.A. Gadomskii, Russkaia teolingvistika: istoriia, osnovnye napravleniia issledovanii. Biblioteka serbskoi kul'tury "Rastko», //www.rastko.rs/filologja/stil/2010/27Gadomski.pdf

20. R.I. Goriushina, Leksika khristianstva v russkom iazyke (sistemnye otnosheniia priamykh konfessional'nykh i proizvodnykh svetskikh znachenii slov) Dissertatsiia 
(Volgograd, 2002)

21. V.P. Zaval'nikov, Iazykovoi obraz sviatogo v drevnerusskoi agiografii: Problematika vzaimnoi obuslovlennosti lingvisticheskogo $i$ ekstralingvisticheskogo soderzhaniia iazykovogo obraza cheloveka v opredelennoi sotsiokul'turnoi situatsii: avtoreferat dis. (Omsk, 2003)

22. A.M. Kamchatnov, Sakral'nyi slavianskii iazyk v Tserkvi i kul'ture. Sovremennoe obnovlenchestvo - protestantizm «vostochnogo obriada» (M., 1996) http://www.philology.ru

23. I.A. Koroleva, Pravoslavnaia sakral'no-bogoslovskaia leksika v sovremennom russkom iazyke i $v$ khudozhestvennom tekste: avtoreferat dis. (Volgograd, 2003)

24. O.A. Matveeva, Tserkovnoslavianskaia leksika kak terminosistema (M., 2013)

25. N.B. Mechkovskaia, Iazyk i religiia: Lektsii po filologii i istorii religii (M., 1998)

26. E.N. Nikulina, Agiologiia: kurs lektsii (M., 2008)

27. S.A. Smirnova, Sviatost' kak fenomen russkoi kul'tury: Semanticheskoe $i$ lingvokul'turologicheskoe opisanie: dissertatsiia (Severodvinsk, 2005)

28. K.A. Timofeev, Religioznaia leksika russkogo iazyka kak vyrazhenie khristianskogo mirovozzreniia, http://www.philology.ru

29. A.A. Chernobrov, Spetsifika religioznogo diskursa v lingvistike (Obrazovanie i kul'tura Rossii v izmeniaiushchemsia mire), http://www.philology.ru

30. I.V. Bugaeva, The Dictionary of accents of religious vocabulary. Dictionary of religious vocabulary: Russian language (Moscow, Orthodoxy, 2009)

31. V.M. Zhivov, Holiness. Concise Dictionary of hagiographic terms (M., 1994)

32. L.P. Klimenko, Dictionary of figurative, picturesque and symbolic words in the Psalter (Nizhny Novgorod, 2008)

33. O.A. Sedakova, Dictionary of Difficult Words from the Liturgy: Church SlavonicRussian paronyms (Moscow, 2008)

34. G.N. Sklyarevskaya, Dictionary of Orthodox Church Culture (Saint Petersburg, 2000)

35. Iu.V. Koreneva, Gnezdo slov kornia * SVET. Explanatory Dictionary of the Living Great Russian Language (1863-1866) http://slovari.ru/default.aspx?s=0\&p=246

36. Ibid Dictionary of The Russian Academy (Saint Petersburg, 1794) http://etymolog.ruslang.ru/doc/SAR5_P-S.pdf

37. Materials for the dictionary of the Old Russian language. The works of Sreznevsky I.I., http://etymolog.ruslang.ru

38. Dictionary of the Old Russian Language (XI-XIV centuries) (2016)

39. Dictionary of the Russian language XI-XVII centuries (M., Nauka, 1975) http://etymolog.ruslang.ru/index.php?act=xi-xvii

40. Dictionary of the Church Slavonic and Russian language, compiled by the Second Department of the Imperial Academy of Sciences. In 4 vols (Saint Petersburg, 2001)

41. V.I. Dahl, Explanatory Dictionary of the Living Great Russian Language (1863-1866) http://slovari.ru/default.aspx?s=0\&p=246

42. Explanatory dictionary of the Russian language: In 4 vols, https://ushakovdictionary.ru/view_search.php

43. Dictionary of the Russian language: In 4 vols, http://slovari.ru/default.aspx?s=0\&p=240

44. Dictionary of the Russian Language by Ozhegov S.I. and Shvedova N.Yu, 
http://slovari.ru/default.aspx?s=0\&p=244

45. Graph of the lexeme, http://search1.ruscorpora.ru/plot.xml?smoothing $=3 \&$ stat $=$ gr_created_\&env $=$ alpha\&my corp $=\&$ mysent $=\&$ mysize $=\&$ mysentsize $=\&$ mydocsize $=\&$ sp $\overline{\mathrm{d}}=\&$ text $=$ lexgramm $\&$ mode $=$ main\&sort $=$ gr tagging\&lang $=$ ru\&nodia $=1 \&$ parent $1=0 \& l e v e l 1=0 \& l e x 1=\% \mathrm{~F} 1 \% \mathrm{E} 2 \%$ $\mathrm{FF} \% \mathrm{~F} 2 \% \mathrm{EE} \% \mathrm{E} 9 \&$ gramm $1=\&$ sem $1=\&$ sem-mod $1=$ sem\&sem$\bmod 1=\operatorname{sem} 2 \&$ flags $1=\& \mathrm{~m} 1=\&$ parent $2=0 \&$ level $2=0 \& \min 2=1 \& \max 2=1 \&$ lex $2=\&$ gram $\mathrm{m} 2=\& \operatorname{sem} 2=\& \operatorname{sem}-\bmod 2=\operatorname{sem} \& \operatorname{sem}-\bmod 2=\operatorname{sem} 2 \&$ flags $2=\& \mathrm{~m} 2=\#$ toggle

46. Graph of the lexeme, http://search1.ruscorpora.ru/plot.xml?smoothing $=3 \&$ stat $=$ gr_created_\&env $=$ alpha\&my corp $=\&$ mysent $=\&$ mysize $=\&$ mysentsize $=\&$ mydocsize $=\& \mathrm{sp} \overline{\mathrm{d}}=\&$ text $=$ lexgramm $\&$ mode $=$ main\&sort $=$ gr tagging\&lang $=$ ru\&nodia $=1 \&$ parent $1=0 \&$ level $1=0 \& l e x 1=\% \mathrm{~F} 1 \% \mathrm{E} 2 \%$ $\mathrm{FF} \% \mathrm{~F} 2 \% \mathrm{EE} \% \mathrm{~F} 1 \% \mathrm{~F} 2 \% \mathrm{FC} \&$ gramm $1=\&$ sem $1=\&$ sem-mod $1=$ sem $\&$ sem$\bmod 1=$ sem $2 \&$ flags $1=\& \mathrm{~m} 1=\&$ parent $2=0 \&$ level $2=0 \& \min 2=1 \& \max 2=1 \&$ lex $2=\&$ gram $\mathrm{m} 2=\& \operatorname{sem} 2=\& \operatorname{sem}-\bmod 2=\operatorname{sem} \& \operatorname{sem}-\bmod 2=\operatorname{sem} 2 \&$ flags $2=\& \mathrm{~m} 2=$

47. Graph of the lexeme, http://search1.ruscorpora.ru/plot.xml?smoothing=3\&stat=gr_created_\&env=alpha\&my corp $=\&$ mysent $=\&$ mysize $=\&$ mysentsize $=\&$ mydocsize $=\&$ sp $\overline{\mathrm{d}}=\&$ text $=$ lexgramm $\&$ mode $=$ main\&sort $=$ gr_tagging\&lang=ru\&nodia $=1 \&$ parent $1=0 \&$ level $1=0 \& l e x 1=\% \mathrm{~F} 1 \% \mathrm{E} 2 \%$ $\mathrm{FF} \% \mathrm{~F} \%$ \%5\%ED \%ED\%FB\%E9\&gramm1=\&sem $1=\&$ sem-mod $1=$ sem\&sem$\bmod 1=\operatorname{sem} 2 \&$ flags $1=\& \mathrm{~m} 1=\&$ parent $2=0 \&$ level $2=0 \& \min 2=1 \& \max 2=1 \& l e x 2=\&$ gram $\mathrm{m} 2=\& \operatorname{sem} 2=\& \operatorname{sem}-\bmod 2=\operatorname{sem} \& \operatorname{sem}-\bmod 2=\operatorname{sem} 2 \&$ flags $2=\& \mathrm{~m} 2=$

48. Dictionary of the Russian language: In 4 volumes. Academy of Sciences of the USSR, Institute of Russian language (M., The Russian language, 1981-1984) http://slovari.ru/default.aspx?s=0\&p=240

49. V.V. Kolesov, Iazykovye osnovy russkoi mental'nosti: ucheb. posobie (M., 2017)

50. Drevoslov, http://www.drevoslov.ru/ 